\title{
A Pre Post-COVID-19 Pandemic Review of Regional Connectivity and Socio-Economic Development Reforms: What Can Be Learned by Central and Eastern European Countries from the China-Pakistan Economic Corridor
}

\author{
Atta Ullah iD https://orcid.org/0000-0002-0590-563x \\ Ph.D. (Scholar), School of Management, Institutes of Poverty Reduction \\ and Development, Huazhong University of Science and Technology \\ Wuhan, P.R. China, e-mail: attaullah142@hust.edu.cn \\ Chen Pinglu iD https://orcid.org/0000-0003-4840-957x \\ Prof., School of Management, Chair of Financial Management Department \& Vice \\ Dean at Institutes of Poverty Reduction and Development, Huazhong University \\ of Science and Technology, Wuhan, P.R. China, e-mail: cplcmhust@hust.edu.cn
}

Saif Ullah iD https://orcid.org/0000-0002-1205-6250

Ph.D, (Candidate), Faculty of Management Sciences, SZABIST Karachi, Pakistan e-mail: saifullah_142@yahoo.com

Muhammad Ather Elahi (iD https://orcid.org/0000-0002-4508-4434

Ph.D., Assistant Professor, Imam Abdul Rahman Bin Faisal University

Dammam, Saudi Arabia, e-mail: maelahi@iau.edu.sa

\begin{abstract}
This paper aims to highlight the role of mutual assistance of China and Pakistan's regional connectivity through the China-Pakistan Economic Corridor (CPEC) and show what lessons can be learned by Central and Eastern European Countries (CEECs). CPEC promotes trade, FDI, peace, and sustainable socio-economic development, and it can help to alleviate the effects of COVID-19 in the region to promote socio-economic
\end{abstract}


development. In this study, we employed the Rolling Window Approach (Rolling Moving Average Approach) for data analysis of pre- and post-COVID-19. It also focuses on before and after the CPEC initiative's impact on the Pakistani economy through the Rolling Window Approach and graphical trends. In Pakistan, thanks to CPEC; trade, FDI, remittance, and the stock exchange (PSX) showed an upward shift. Terrorism decreased, which indicates a positive sign for peace and socio-economic development. However, currency depreciation increased, and the exchange rate trend is going up against the dollar, hurting the economy badly in several ways, such as the balance of payment, current account deficit, and lower some exports. To mitigate these issues, Pakistan and China have taken steps as trade formulated in domestic currency between China and Pakistan. During COVID-19, the provision of health care equipment on a priority basis from China helped to combat the COVID-19 effects and stabilize Pakistan's Economy. CPEC is structured to connect regional economic zones by forming local, regional, and global value chains. To cope with the COVID-19 impacts, socio-economic reforms and regional cooperation are suggested for CEECs with a pre-post circumstances review. Regional integration and cooperation are key to coping with this pandemic. CEECs can learn lessons from CPEC for socio-economic development, reducing violence, and improving the economy.

Keywords: China-Pakistan Economic Corridor (CPEC), exchange rate, FDI, violence, technology, socio-economic development, COVID-19 pandemic

JEL: P25, P48, R11, F36, F63

\section{Introduction}

China plays a dominant role, not only in the Asian region but also the entire world, especially after the successful quick response to and combating COVID-19, which started in Wuhan at the beginning of 2020. China is the largest country in the world population-wise, and it is becoming economically stable with an efficient financial system. According to Tambo et al. (2019), China's Belt and Road Initiative is estimated to exceed 1 trillion USD. The initiative involves more than 65 countries to link China with Asia, Europe, the Middle East, and Africa. The direct and indirect global developmental impacts can be separated into four categories: (1) Information harnessing, technology, and health, (2) Eased commerce \& trade, (3) Augmented energy resource safety, (4) Improvements towards the planet.

Development is a prerequisite for economic development, and it is a by-product of the industrial growth process (Acemoglu and Robinson 2013). However, Law, Tan, and Azman-Saini (2015) said that primary sources were driven by financial reform policies, the legal system, public banks, cultural norms, and political institutions for development. In the last several decades, economic development and economic integration have been increased in parallel by enhancing investment and international trade. In light of this century's recession, there are potential opportunities to ascertain the impact of finance and integration on economic development. Abid and Ashfaq (2015) 
reported that the China-Pakistan Economic Corridor (CPEC) is part of China's "One Belt One Road" initiative, and initially, the total estimated investment was $\$ 46$ billion. The standing value was $\$ 62$ billion, which became the highest investment from China to any integration collation partner country.

Pakistan has suffered a lot from terrorism, natural disasters (like the earthquake of 2005 or the flood of 2010), economic deprivation, and the most importantly, energy crises. Socio-economic development is the backbone of any country, which lays the road map for its success. It has been observed worldwide that countries succeed when they have sound health care and energy policies. Under CPEC, most energy projects were constructed by private independent power producers instead of government-owned projects. In the case of Pakistan, there are 14 different units of energy entities - four thermal power generation companies (GENCOs), one company managing the transmission of power (NTDC), and nine electricity distribution companies (DISCOs). The leading holding company of these units is Pepco (the Pakistan Electric Power Company).

Various energy projects in Pakistan are expected to generate electricity from fossil fuels such as coal. Of the total stake money for projects, $\$ 11$ billion at the introductory level was used to develop transportation networks to create a link from Gawadar and Karachi, on the coast of the Arabian Sea in the south, to northern areas of Pakistan, and on to China and Central Asia as per Ministry of Planning, Pakistan. However, the ongoing COVID-19 pandemic effect worldwide has significantly impacted the stability, poverty, and development of developed and developing countries. For example, as stated by the Pakistan Institute of Development Economics (PIDE) in Islamabad, around 70 million of the country's population could fall below the poverty line, 18.5 million people could lose their job, and more than one million small businesses could be shuttered forever in the current perspective of COVID-19. Additionally, the economy will sustain a 2.5 trillion rupee loss in three months. Figure 1 shows the overall statistics of COVID-19 from the first case date up to May $24^{\text {th }}, 2020$.

The CPEC project has enormous importance for developing countries like Pakistan and the other linked countries and China because the route through the corridor from Gawadar is easy and, vitally, it provides the shortest access to the Middle East. The China-Pakistan economic corridor builds a connection of infrastructure, production, and trade within specific geographical urban and rural entities. This industrial corridor is structured to create domestic, regional, and global value chains to connect economic zones and hubs. The CPEC passage is not just for the transit of goods, services, and people but also for export-oriented and high tech industries (Hussain, Mehmood, and Saeed 2017). This prominent CPEC value-added project directly connects China and Pakistan (Fouzia and Aban 2018).

The Pakistani rupee has lost about a quarter of its value against the US dollar due to trade deficit, poor governance, and economic policies. Pakistan's foreign exchange reserves fell to a near five-year low of US $\$ 7.8$ billion in November 2018, as reported by the state bank of Pakistan, while the net foreign reserves held by commercial banks 
also dropped to US $\$ 6.4$ billion. In the first week of November 2018, as the fiscal crisis loomed, the newly elected Prime Minister of Pakistan and his team visited China. The aim was to strengthen the initiatives to improve the reforms of the CPEC regional connectivity policies to take them to the next level of financial integration, and they also formulated a mechanism to trade in domestic currencies instead of the dollar.

Covid-19 Cases Situation in Pakistan
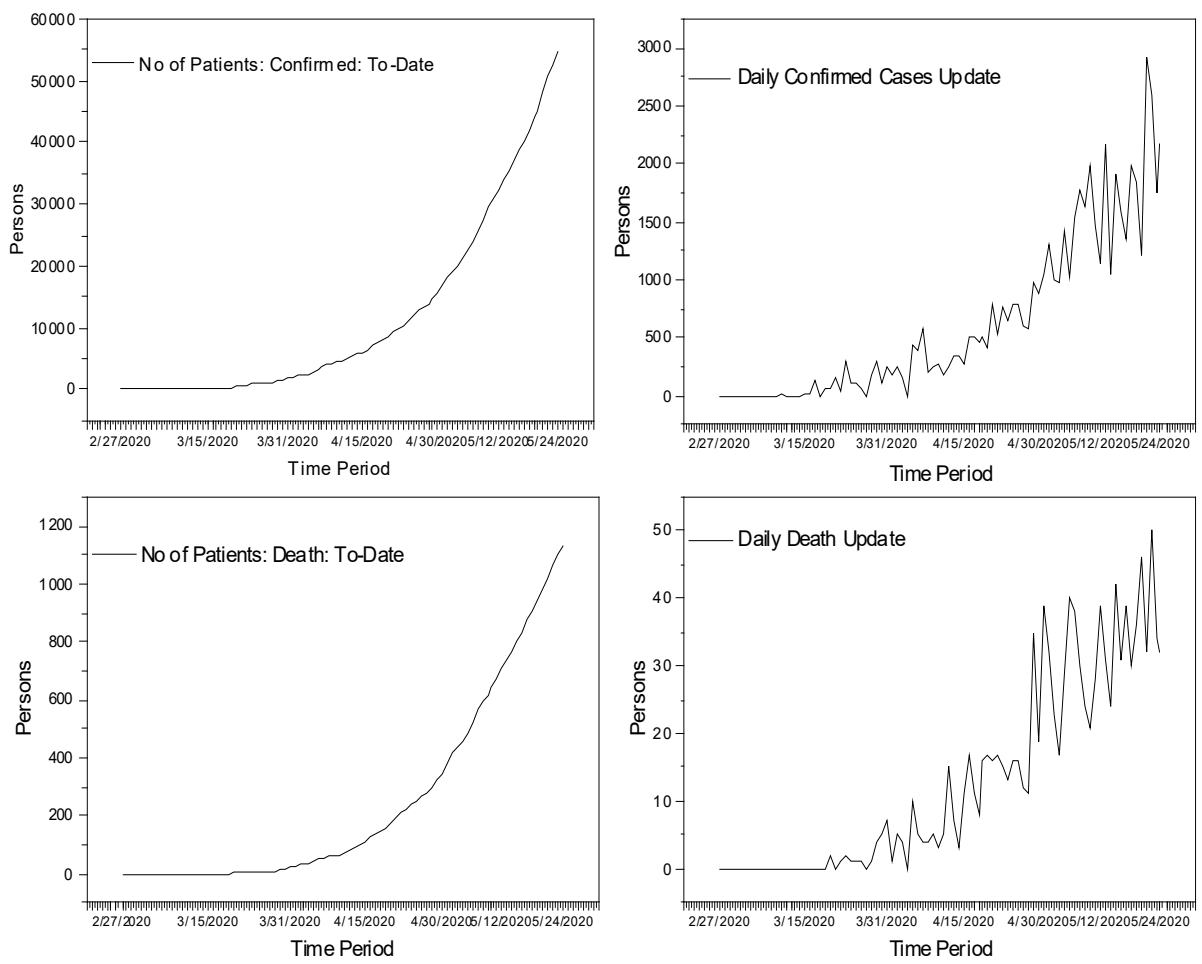

Figure 1. Covid statistics in Pakistan

Source: authors own estimation using OriginPro 2018 based on WHO and CEIC data.

Recent economic integration policies, and the relationship between both countries, increased the focus on regional connectivity, growth, sustainable socio-economic development through CPEC integration, domestic currency exchange, and better governance policies. They also raise the question of how they can mutually deal with financial crises and poverty alleviation for sustainable socio-economic stability, especially with the COVID-19 pandemic and its effects. Therefore, it is necessary to address the nexus between regional connectivity through the CPEC, socio-economic development reforms, and the COVID-19 pandemic.

The study's primary purpose is to highlight the role of China and Pakistan's mutual assistance in regional connectivity through CPEC, financial integration in trade, domestic currencies instead of the US dollar, and foreign direct investment. It also 
aims to highlight the role of combating the effects of COVID-19, peace against violence, technology in Pakistan through CPEC for the transformation of expertise and advancement, as well as human and socio-economic development in the region. Moreover, it focuses on determining Pakistan's Financial Times Stock Exchange (FTSE) price index and the Pakistan Stock Exhange (PSX) formally known as Karachi Stock Exchange (KSE)-100 index trends for the era of financial crises, before and after the CPEC initiative in Pakistan. The regional development may benefit way forward in the understating of combating the COVID-19 effect.

The contribution of the study is that it shows that thanks to the CPEC initiative in Pakistan, trade, FDI, remittance, and the PSX Index showed an upward shift while terrorism decreased, indicating a positive sign for Pakistan and world peace, and social and economic development. However, currency depreciation increased in Pakistan, and to mitigate these issues, Pakistan and China have taken steps to trade in domestic currency. The results will help stabilize Pakistan's economy, but governance reforms and policies take time. CPEC provides the Chinese economy with a gateway to the world, while it helps Pakistan combat the effects of COVID-19 based on China's successful experience; CPEC also brings prosperity and peace to the region.

The study has policy implications and lessons to learn for Central and Eastern European Countries (CEECs). CEECs can learn from the experience of CPEC and other mutual assistance initiatives among the countries of the Belt and Road Initiative (BRI). This mutual assistance and cooperation among CEECs can further enhance sustainable development, reduce terrorism, promote investment and help the economy. The reduction in terrorism and enhancement in investment may improve the social wellbeing of the populations who share a development.

\section{Review and background literature}

\section{Regional connectivity}

Under the BRI, CPEC is a significant initiative and considered a "game-changer" for Pakistan. It aims to connect the southern port of Gwadar with the northern areas of Pakistan, and onto China, via the ancient Silk Road city of Kashgar in the far west of the country. The total distance is about $3124 \mathrm{~km}$; therefore, the corridor can help to move Iraq, Iran, and Middle Eastern countries' exports of liquefied natural gas, and many more, away from the sea towards the train or pipelines. The Karot hydropower project was launched under the Silk Road Fund and cost the US $\$ 1.61$ billion, funded by financial institutions and Export-Import Bank loans (Lee et al. 2017).

The primary purpose of CPEC is to enhance trading activities between China, Pakistan, the Middle East, Africa, and Central Asia (Aftab 2018). In the field of public health, immense opportunities are offered by the BRI, involving multiple countries 
for partnership and collective actions to fight globalization-related emerging pandemics, infectious or chronic diseases, and outbreaks of potential threats to both health information management and laboratory information management systems. Worldwide geo-economics may improve due to strengthening the health system for public health initiatives (Tambo et al. 2019).

\section{Concept of socio-eonomic development}

The basic principle of socio-economic development (SED) is to develop by maximizing the economic potential and establishing an efficient system in the region. By necessity, SED applies a long-term perspective for promoting prosperity because the economic structures on all scales are changing, and development is related to the local situation and vice versa. Developing countries usually lack these opportunities for innovation, competition, and investment due to corruption, political instability, violence, and poor fiscal management. About 2.6 billion people live on less than $\$ 2$ a day worldwide, which means that sustainable economic growth can be an essential tool. However, due to COVID-19, poverty will rise at a colossal level, and the impact will be remembered for decades, according to the e-book from PIDE on COVID-19 (2020).

Rahman et al. (2018) stated that Universal health coverage (UHC), as a global health priority, is a key objective of the Sustainable Development Goals (SDGs), which ensure the provision of superior health facilities to all citizens when they needed without financial risk. As defined by the World Health Organization, in improving health financing reform, all member countries must achieve a set of UHC targets by 2030 . At least $80 \%$ of a country's population must have access to essential health-service coverage and be guaranteed protection from impoverishing and catastrophic expenses for health facilities by 2030, regardless of their gender, where they love, or economic status.

Aside from economic factors, a country should also focus on non-state actors, ethno-religious diversity, and party politics because these factors also give rise to terrorism and can damage the country (Piazza 2006). It is essential for Pakistan that it should continue its efforts to sustain peace with its eastern and western neighbors, essential for Pakistan's future security and economy. Efforts should also be made to reduce the regional disparities to bring peace within the state (Butt and Butt 2015).

\section{Data and measurement}

This study explores the impact of regional connectivity and financial integration in combating COVID-19 effects to promote socio-economic development for analysis and discussion. It also aims to discover whether before/after CPEC initiative trends are increasing or decreasing. This study discusses economic integration in domestic currencies instead of the dollar, currency depreciation trends, trade, FDI, remittances, and 
Pakistan stock exchange index (PSX). This study highlights the China and Pakistan regional connectivity through CPEC to ensure the socio-economic development reforms. Additionally, we want to find out the consequences of the recent ongoing COVID-19 impacts. The monthly closing average of the year was collected from 2003 to 2019, along with the latest updated data from 2020 related to COVID-19 from reliable sources. The State Bank of Pakistan's exchange rate and stock return data were collected from the PSX website. The bilateral trade data between mainland China and Hong Kong, import, export, and GDP were gathered from the State Bank of Pakistan.

We also focus on determining the efficiency of the financial crisis-era, before and after the CPEC initiative in the Pakistan market growth and regional development benefits. The Pakistan Financial Times Stock Exchange Index (FTSE) and PSX (KSE100 index) trend for assessing economic condition are considered in this study. Data of the FTSE index of Pakistan is collected from Data Stream. Internationally, the country suffers from a terrible image problem, and we highlight terrorism because Pakistan is included among those countries that suffer a lot from terrorist activities and bear whose economies and social growth are affected. We gathered monthly data from the South Asia Terrorism Portal (www.satp.org) to determine the trends of violence against peace and socio-economic development in the region. Terrorism data is available from 2003 to date; therefore, all data were gathered from 2003 to 2019 to determine and demonstrate the graphical trends of violence, fatalities, and socio-economic development in the region.

In this study, we employed the Rolling Window Approach (Rolling Moving Average Approach). When we measure the financial crisis's effect, CPEC efficiency, and performance on different sectors, using the monthly rolling moving average approach shows more volatility. A moving average cycle shows more profitability and helps to make investment appraisal and decision-making (Liu et al. 2017). After employing the rolling moving averages, we divided the total sample period into pre-CPEC and after integrating the CPEC initiative period. We also compare these results with the PSX (KSE-100) and Pakistan FTSE performance to discover whether these trends are consistent with stock exchange performance during this period because the stock market was also found to be affected during the global financial crisis period (Ali and Afzal 2012).

\section{Discussion and comparison}

Regional connectivity of CPEC, socio-economic development, and COVID-19 factors are discussed and compared in the following sections. 


\section{Technology and human development for Pakistan}

In 1960, when technology advanced in telecommunication, computation, and data processing, transaction costs in financial services fell. It created new markets that implemented these innovations and gave long term benefits for trading (Merton and Bodie 1995). China and Pakistan's advancements in and technology and e-government rankings are shown in Figure 2. Countries are ranked from 1 (best) to 194 (worst), and Figure 2 shows that China's e-government ranking improved from 74 in 2003 to 65 in the latest report from 2018. The factors mentioned above related to human technology and human capital helped China successfully to combat the COVID-19 pandemic situation. Figure 2 also that in 2014, Pakistan ranked $158^{\text {th }}$ out of 193 while in 2018, it had moved up to 148 out of 193, which indicates that four years after the CPEC initiative was implemented, it had improved by ten places; therefore, this is a good sign for Pakistan.

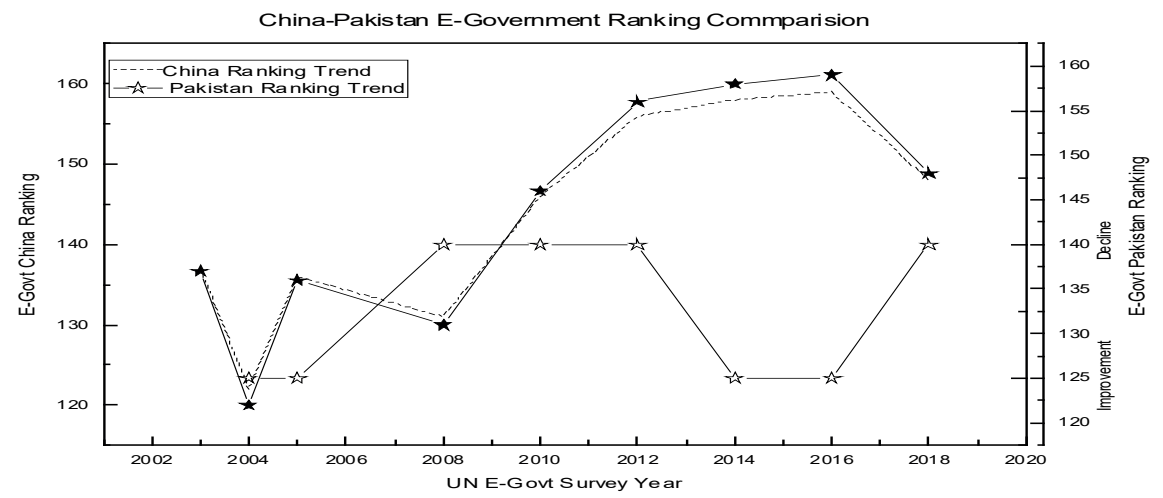

Figure 2. China-Pakistan E-Government Ranking out of 194 countries

Source: data obtained from United Nations survey reports; author's estimates through OriginPro 2018 software.

Under the CPEC economic integration, Pakistan has a chance to get maximum skills, support, and technological advancement benefits from Chinese success to develop expertise in these areas. From the economic point of view, the concept of paperless currency, like Alipay and Wechat, used in China is more beneficial for an effective tax system, control of corruption, money laundering, and other control measures related to money during emergencies like the COVID-19 lockdown. Around about 22,000 Pakistani students are in China, which is a good sign for Pakistan in human development. It will be beneficial for Pakistan's development when Chinese technologies are adopted, especially from CPEC projects. Pakistan may benefit from the latest technology of China under CPEC to successfully combat the COVID-19 effects and future sustainable development.

The establishment of technology and research programs to train human resources with China's expertise will be mutually beneficial for both countries in various fields, 
such as artificial intelligence, energy, agriculture, nanotechnology, space technology, biotechnology, and management. In Pakistan, with the current pace of development under CPEC, it is estimated that Pakistan's GDP would increase by $2.5 \%$, creating 700,000 jobs in the areas mentioned by 2030. However, due to COVID-19, the current situation is uncertain and needs an efficient model of re-assessment.

\section{Violence against peace and development}

Nowadays, violence has emerged as one of the most dangerous and destructive phenomena against global peace and security. The impetus of violence and turmoil has enhanced global issues, and it has posed severe challenges to the progressive socio-economic notions of the World. Violence has affected the whole world, and almost every state must spend a portion of its budget on counter-terrorism and terrorists. Pakistan and China have an all-weather friendship, and CPEC is a real example of that friendship. China's public management system is capable and controlled, while Pakistan can adopt reforms, management systems, and technology expertise to diminish internal terrorism and corruption for effective internal control and security.

Unfortunately, Pakistan has suffered regarding socio-economic stability and maintaining peace and security. A continuous wave of anti-state terrorism and sectarianism violence since 9/11 have resulted in protracted turmoil and intensified violence. Neighbor Afghanistan has a war link with 9/11, and there have been border skirmishes with Pakistan; therefore, the 18 years of the War on Terror resulted in massive human and economic losses.

At least 80,000 Pakistanis have killed in the war on terror, and more than 95,000 injured as per NACTA (National Action Counter Terrorism Authority) Pakistan in this so-called war against terrorism. According to NACTA, Pakistan spent estimated \$123.13 billion, equivalent to PKR 10.373 trillion, on counter-terrorism measures and military operations. The number of fatalities as per the South Asia portal is shown in Table 1, while the terrorist/violence trend in Pakistan is shown in Figure 3.

Table 1. Numbers of fatalities of terrorist violence in Pakistan

\begin{tabular}{|l|c|c|c|c|}
\cline { 2 - 5 } \multicolumn{1}{c|}{} & $\begin{array}{c}\text { No. } \\
\text { of Civilians }\end{array}$ & $\begin{array}{c}\text { No. of Security } \\
\text { Force Personnel }\end{array}$ & $\begin{array}{c}\text { No. of Insurgents/ } \\
\text { Terrorists }\end{array}$ & $\begin{array}{c}\text { Total No. } \\
\text { of Deaths }\end{array}$ \\
\hline Total from the year 2003-2018 & 22,504 & 7,014 & 34,036 & 63,554 \\
\hline Total till December 2019 & - & - & - & 63,722 \\
\hline
\end{tabular}

Source: South Asia Portal (December 2019). 


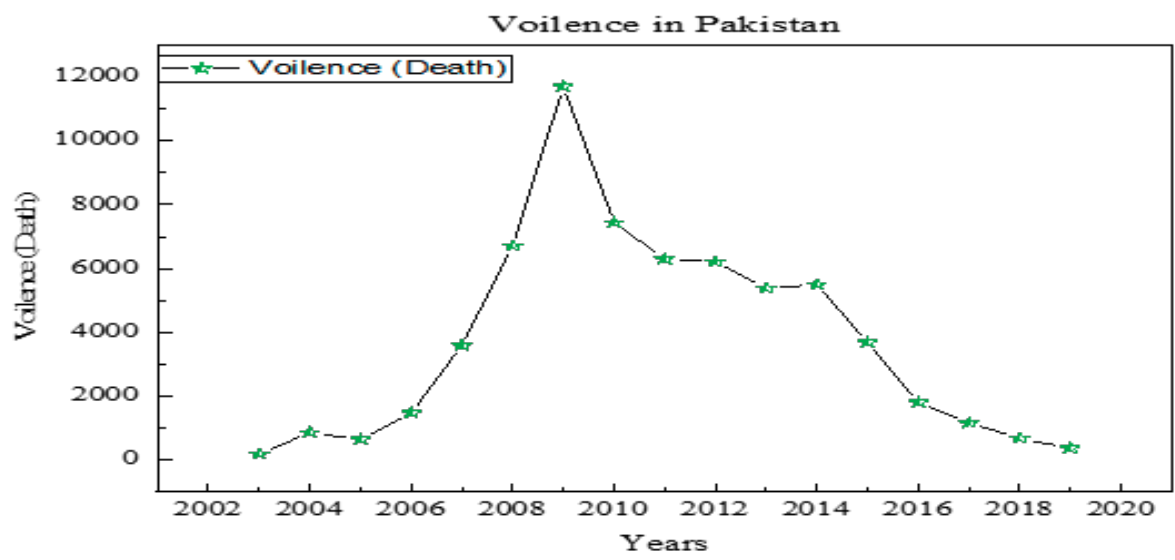

Figure 3. Trend of violent deaths in Pakistan

Source: data obtained from South Asia Terrorism Portal (www.satp.org); author's estimates through OriginPro 2018 software.

The trend in Figure 3 supports the anti-terrorism action plan and many operations, such as Zarb-e-Azb and Karachi, against terrorists to improve the country's overall violent situations. Figure 3 also demonstrates that after 2015, there was a rapid decrease in terrorist activities and deaths, indicating that after regional connectivity through CPEC integration and strict successful measures under the national action plan, Pakistan is again a safe country. Therefore, it can now play a significant role in the development of the region. However, ongoing initiatives need to create a long-term sustainable socio-economic situation and better representation. Pakistan's economy continues to maintain its growth momentum for the $3^{\text {rd }}$ year in a row, with real GDP growing at 4.56 percent in 2016, 5.37 percent in 2017, and 5.79 percent in 2018, which is the highest in eight years (Pakistan Economic Survey, 2017-2018). However, it then fell in 2019 due to financial and political instability and inadequate policies, and it will decline further due to COVID-19 effects; therefore, it needs better policies and reforms soon.

\section{Foreign Direct Investment (FDI) and remittances}

Table 2 shows that foreign direct investment increased considerably after the integration of CPEC, which positively impacted the country. However, due to the recent ongoing COVID-19 pandemic and lockdown situation, there has been a decrease in investment activities and remittances worldwide. The detailed foreign direct investment inflows between China and Pakistan are shown below in Table 2. 
A Pre Post-COVID-19 Pandemic Review of Regional Connectivity...

Table 2. Foreign direct investment from the world, mainland China, and Hong Kong (USD millions)

\begin{tabular}{|c|c|c|c|c|c|c|c|}
\hline $\begin{array}{c}\text { Financial } \\
\text { Year }\end{array}$ & $\begin{array}{c}\text { FDI } \\
\text { Pakistan } \\
\text { from all } \\
\text { World }\end{array}$ & $\begin{array}{c}\text { Remittances } \\
\text { from all } \\
\text { World }\end{array}$ & $\begin{array}{c}\text { All World } \\
\text { Total } \\
\text { Investment } \\
\text { into } \\
\text { Pakistan } \\
\text { (GDP \%) }\end{array}$ & $\begin{array}{c}\text { FDI from } \\
\text { Mainland } \\
\text { China }\end{array}$ & $\begin{array}{c}\text { FDI } \\
\text { from } \\
\text { Hong } \\
\text { Kong }\end{array}$ & $\begin{array}{c}\text { Total FDI } \\
\text { China } \\
\text { + Hong } \\
\text { Kong }\end{array}$ & $\begin{array}{c}\text { Total FDI+ } \\
\text { FPI into } \\
\text { Pakistan } \\
\text { from } \\
\text { China } \\
\text { + Hong } \\
\text { Kong }\end{array}$ \\
\hline $2009-2010$ & 531.77 & 3962.96 & 17.549 & $(3.6)$ & 9.9 & 6.3 & 25.5 \\
\hline $2010-2011$ & 1117.26 & 3943.93 & 15.805 & 47.4 & 125.6 & 173 & 196.2 \\
\hline $2011-2012$ & 2200.34 & 4277.85 & 14.121 & 126.1 & 80.3 & 206.4 & 73.2 \\
\hline $2012-2013$ & 4272.45 & 5112.94 & 15.076 & 109.8 & 244.7 & 354.5 & 262.2 \\
\hline $2013-2014$ & 5590.54 & 5991.96 & 14.957 & 745.8 & 230.1 & 975.9 & 990.6 \\
\hline $2014-2015$ & 5436.87 & 7024.92 & 14.635 & 1121.6 & 138.0 & 1259.6 & 403.2 \\
\hline $2015-2016$ & 2338.36 & 8701.60 & 15.707 & 1108.8 & 95.5 & 1204.3 & 1144.3 \\
\hline $2016-2017$ & 2021.57 & 9667.15 & 15.686 & 1265.7 & 23.0 & 1288.7 & 1014.4 \\
\hline $2017-2018$ & 1326.27 & 12234.89 & 16.094 & 1907.2 & 4.9 & 1912.1 & 1635.2 \\
\hline $2018-2019$ & 1332.84 & 14597.34 & - & - & - & - & - \\
\hline
\end{tabular}

Source: State Bank of Pakistan (FDI Inflows in USD millions from financial year July to June)

\section{Bilateral trade, import, and exports}

In this era of globalization, every country seeks export growth since exports are the economic growth engine to accelerate the development process. Through exports, local firms could achieve economies of scale, profitability, globalization, and internationalization. As an agricultural country and the world's seventh-largest producer of cotton, $\mathrm{Pa}$ kistan's textile sector has potential. However, Ahmad, Abdullah, and Roslan (2012) said that during and after the beginning of the financial and electricity shortfall crisis, the country's textile industry shifted to India and Bangladesh, the latter's main reason for relatively liberal export incentive schemes with other countries. According to the World Bank, globally, Pakistan's exports declined to $13 \%$ from $18 \%$. However, after completing some energy projects recently after 2018 , textile and other sectors have improved.

In Pakistan, since the financial year 1981-1982, the highest single decline in exports was recorded in 2015-2016, by 13\% (State Bank of Pakistan 2017). As export growth is the best strategy to overcome weak economic growth by utilizing useful projects like CPEC, Pakistan must accelerate export performance. In 2013, when China Pakistan initiated CPEC, international oil and gas prices were low, which benefitted Pakistan. Also, before and during COVID-19, oil prices were at an all-time low, which benefited both countries and will benefit China and Pakistan in the future as both countries are oil importers. Therefore, the import of oil through CPEC passage will reduce the cost and time for China. If we look at Pakistan's overall total imports and exports with all countries, the trade portion between Pakistan and China in Table 3 is significant. Due to COVID-19, there is a significant decrease in Pakistan's exports, increasing ex- 
ports for economic growth and minimizing the trade deficit. Table 3 shows imports and exports increased in huge numbers after the integration of CPEC, which positively impacted the country's trade. The detail of the bilateral trade of imports and exports between China and Pakistan and the rest of the world are given in Table 3.

Table 3. Pakistan's bilateral trade with China and worldwide (USD million)

\begin{tabular}{|c|c|c|c|c|c|c|c|}
\hline Year & $\begin{array}{c}\% \\
\text { of export } \\
\text { to China } \\
\text { from } \\
\text { Pak total } \\
\text { Exports }\end{array}$ & $\begin{array}{c}\text { \% of import } \\
\text { from China } \\
\text { to Pak total } \\
\text { exports }\end{array}$ & $\begin{array}{c}\text { PK } \\
\text { Exports } \\
\text { to China }\end{array}$ & $\begin{array}{c}\text { PK imports } \\
\text { from China }\end{array}$ & $\begin{array}{c}\text { Total } \\
\text { Exports } \\
\text { of Pakistan } \\
\text { from all } \\
\text { World }\end{array}$ & $\begin{array}{c}\text { Total } \\
\text { Imports } \\
\text { of Pakistan } \\
\text { from all } \\
\text { World }\end{array}$ & $\begin{array}{c}\text { Trade } \\
\text { Balance }\end{array}$ \\
\hline 2003 & 1.88 & 8.25 & 575.11 & 1855.20 & 11714.08 & 13001.76 & -1287.68 \\
\hline 2004 & 2.00 & 8.30 & 594.78 & 2465.38 & 12943.14 & 17812.85 & -4869.71 \\
\hline 2005 & 2.27 & 8.44 & 832.80 & 3423.03 & 15916.72 & 25331.44 & -9414.72 \\
\hline 2006 & 2.73 & 7.69 & 1007.17 & 4240.73 & 16811.39 & 29824.72 & -13013.33 \\
\hline 2007 & 3.43 & 9.28 & 1105.26 & 5784.92 & 17241.37 & 32596.90 & -15355.54 \\
\hline 2008 & 3.33 & 7.75 & 1007.08 & 5991.41 & 19868.56 & 42131.76 & -22263.20 \\
\hline 2009 & 4.62 & 10.16 & 1258.68 & 5517.65 & 17313.00 & 31699.18 & -14386.18 \\
\hline 2010 & 6.07 & 11.45 & 1730.00 & 6941.66 & 21065.63 & 37817.45 & -16751.81 \\
\hline 2011 & 6.99 & 10.78 & 2122.93 & 8439.15 & 25197.34 & 43989.46 & -18792.11 \\
\hline 2012 & 10.34 & 11.12 & 3141.19 & 9279.08 & 24446.75 & 44156.49 & -19709.74 \\
\hline 2013 & 11.25 & 13.15 & 3207.07 & 11015.62 & 25052.72 & 44699.43 & -19646.71 \\
\hline 2014 & 9.61 & 14.96 & 2760.41 & 13248.54 & 24550.98 & 47547.03 & -22996.05 \\
\hline 2015 & 9.75 & 19.40 & 2478.71 & 16480.78 & 21915.17 & 43843.12 & -21927.95 \\
\hline 2016 & 7.53 & 21.30 & 1902.34 & 17697.83 & 20375.64 & 46845.96 & -26470.32 \\
\hline 2017 & 7.10 & 20.93 & 1831.70 & 18330.39 & 21503.69 & 57281.66 & -35777.97 \\
\hline 2018 & 7.46 & 19.15 & 2183.05 & 16968.24 & 23416.43 & 60052.45 & -36636.02 \\
\hline 2019 & 7.47 & 21.27 & 1950.72 & 15756.53 & 23362.62 & 50573.38 & -27210.76 \\
\hline
\end{tabular}

Source: State Bank of Pakistan \& CEIC.

\section{Pakistan's currency depreciation and domestic and monetary economy}

Currency depreciation is primarily the loss of value of one country's currency compared to other foreign currencies. For many years, Pakistan's currency devalued many times due to worsening economic conditions and its volatility. Devaluation/depreciation is never beneficial for a country. Patro, Wald, and $\mathrm{Wu}$ (2014) showed significant negative abnormal returns before announcing a currency's devaluation.

After the COVID-19 pandemic, on May $12^{\text {th }}, 2020$, the exchange rate was 160.14 PKR to US \$1, an all-time high value with external debt. Figure 4 shows the exchange rate trend with the US dollar between January 2003 and October 2018. It shows that an increase in the dollar rate is causing various economic hurdles for Pakistan. 
Further, stock returns are significantly lower for a higher devaluation of money if it is a developing nation like Pakistan. CPEC plays a significant role in stabilizing the Pakistani economy; for example, Chinese lenders have provided 35 billion USD in loans to Pakistan for energy projects (Dasgupta 2016). Most of the projects are already completed or in the completion stage. However, Pakistan's Government reforms, significant control on corruption, and role in the appreciation of Pakistan's currency can bolster the future economy.

The mega project of CPEC can boost Pakistan's USD 274 billion economy by 15\%, bringing prosperity and progress to the country, lifting the currency. Pakistan has a favorable financial situation; therefore, it makes Pakistan an emerging market that can attract more foreign investment (Abid and Ashfaq, 2015). In Pakistan's challenging economic situation, CPEC proves a game-changer, as the economic corridor can bolster $\mathrm{Pa}$ kistan. China's currency has appreciated by approximately 33\%, which is a good lesson for Pakistan to adopt effective policies like China did to appreciate its currency.

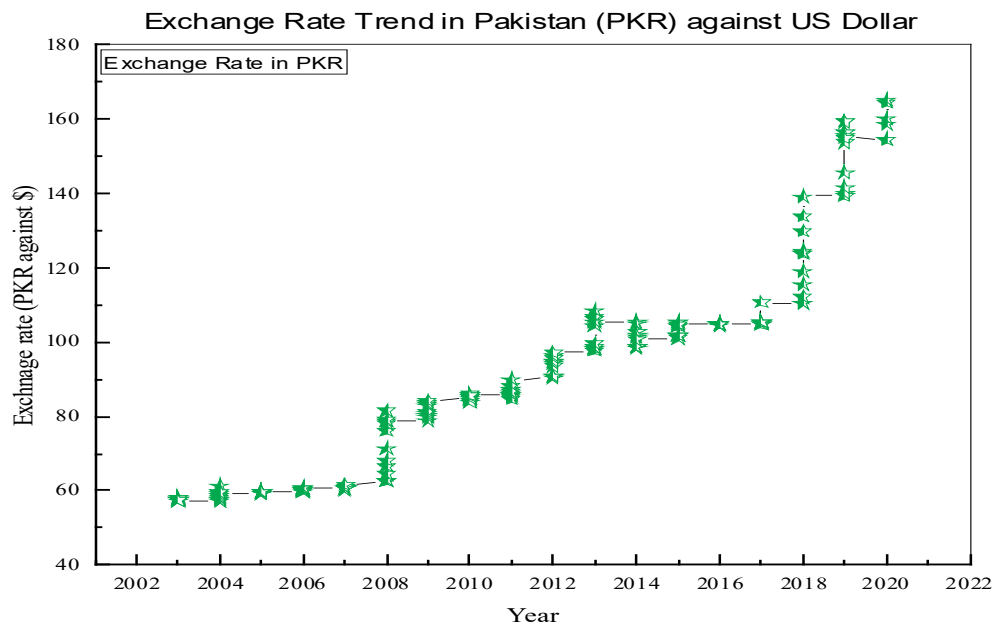

Figure 4. Exchange rate against US dollar trend

Source: data obtained State Bank of Pakistan; Author's estimates through OriginPro 2018 software.

\section{Demonstration and comparison of economic factors}

Pakistan has tried its best to cope with various factors by attracting foreign investment by making good domestic and international relations, improving the ease of doing business, and controlling the law and order situation. The yearly comparison of FDI in Pakistan shown in Figure 5 explains the above argument regarding increasing FDI in Pakistan. It has been observed during the last decade that the labor export rate has risen to $150 \%$, which placed Pakistan among those countries that export a lot of its labor, as it is reported that Pakistan received $\$ 16.034$ billion in the form of foreign remittances compared 
to the previous year's $\$ 15.235$, accounting for a 5.25\% increase (Pakistan Economic survey). A significant portion of Pakistan's economy is based on remittances. The graphical representation is shown in Figure 5.

On December $26^{\text {th }}, 2007$, the Karachi Stock Exchange - KSE-100 index (now known as the Pakistan Stock Exchange - PSX) closed at 14,814 points, with a market capitalization of PKR 4.57 trillion ( $\$ 58$ billion). On January $23^{\text {rd }}, 2009$, the most noteworthy close ever of the KSE-100 stood at 4929 points, with a capitalization of PKR 1.58 trillion ( $\$ 20$ billion), a loss of over 65\%. The KSE-100-listed securities investment rate was high during 2006-2007 but declined, with 58.3\% in December 2008 (Ashraf, Arshad, and Yuancheng 2016).

Figure 6 shows that since 2003, the KSE-100/PSX index touched 45,135.9 in 2017, up from the very crippling positions in 2003 and 2009. During the financial crisis, it faced a downward situation. However, 2018 also shows a decrease due to it being an election year in Pakistan, and history demonstrates that investors decrease the trade and play it safe during this period. During 2019, there is a mixed reaction of increasing and decreasing. However, due to the COVID-19 pandemic, the PSX was down 2106 points, just moments after trading started. International markets fell more than 20 percent until the end of April 2020. The definite trend is demonstrated in Figure 6 below.

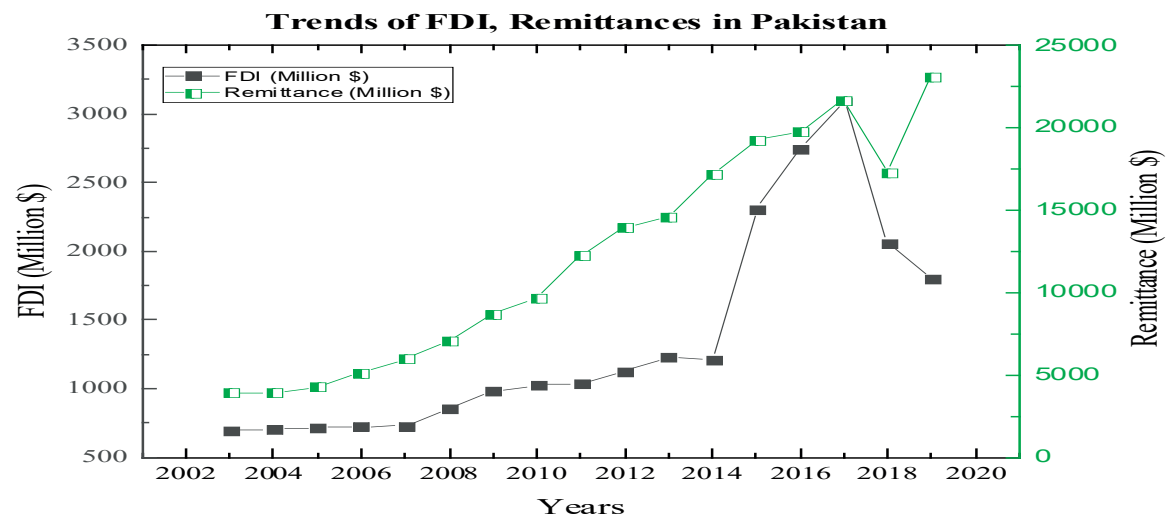

Figure 5. FDI, remittances trends in Pakistan

Source: State Bank of Pakistan; calculations by authors through OriginPro 2018 software.

After the CPEC initiative, statistics significantly influenced the stock market and social and economic development sectors, helping investors to make decisions on the more powerful ground. The rolling moving averages for daily data trends are shown in Figure 6. The graph shows improvements in performance up to 2006-2007, and then a decline in 2008; this trend was seen clearly in 2009. Although, 2007 to mid-September 2008 period is considered the financial crisis period, there was no declining trend; however, after mid-September 2008-2009, i.e., the start of the post-crisis period, the slump in the sector index may have been caused by many reasons. 


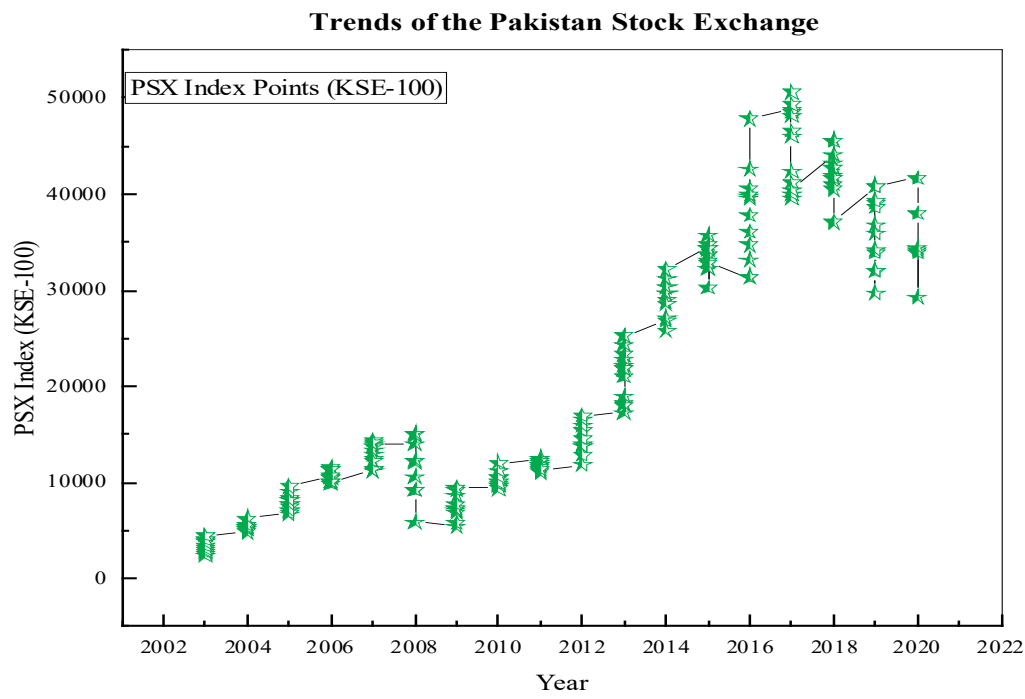

Figure 6. Trends of the Pakistan Stock Exchange (formerly known as the KSE-100 Index) Source: Pakistan Stock Exchange Website; calculations by authors through OriginPro 2018 software.

After the CPEC initiative, the overall economy of Pakistan improved, including the stock market. Before CPEC, Pakistan suffered from political instability, and after the death of Benazir Bhutto in 2007, public violence created a significant decrease in FDI, said to be about $20 \%$. It was also facing the after-effects of the financial crisis in 2009; investors even considered Pakistan an unsafe place. Therefore, FDI further declined to $32 \%$ in mid-2009. Several political events happened because of the ups and downs in the economy, political and justice systems instability, like General Pervaiz Musharraf's resignation and new prime ministers' appointment. The start of the energy crisis caused industry losses.

Floods are another inevitable problem faced by Pakistan, and a major flood in 2009 affected people widely, which may be why laborers could not work in factories, and thus industries faced a loss. Only the agriculture sector benefited. While the rest of South Asian economies endured an immense loss, Pakistan and India improved, as they are extensive rice exporters (Rehman, Zhang, and Ali 2014).

Pakistan's economy during the financial year 2016-2017 recorded a growth of 5.37 percent, which is the highest growth achieved since 2008-2009. Under CPEC, construction sector activities also recorded an impressive growth of 13.10 percent (Pakistan Economic Survey 2016-2017). However, after the CPEC initiative, there is an improvement and a decline because of bad policies and election-year political instability. In the ongoing COVID-19 pandemic, the Government of Pakistan allowed the construction development sector's operation at the start of April 2020 to stabilize the economy after the complete lockdown from February $26^{\text {th }}, 2020$.

Figure 7 shows the Pakistan Financial Times Stock Exchange Index (FTSE). It shows a downward trend during the global financial crisis of 2008-2009, then after the CPEC 
initiative, in the year 2014-2015, an increase; however, again in recent year, there has been a downward shift because of election-year political instability and destructive policies. It is also evident that during the election year, Pakistan faced a decline in trends. The results of the 7-day moving average are shown below.

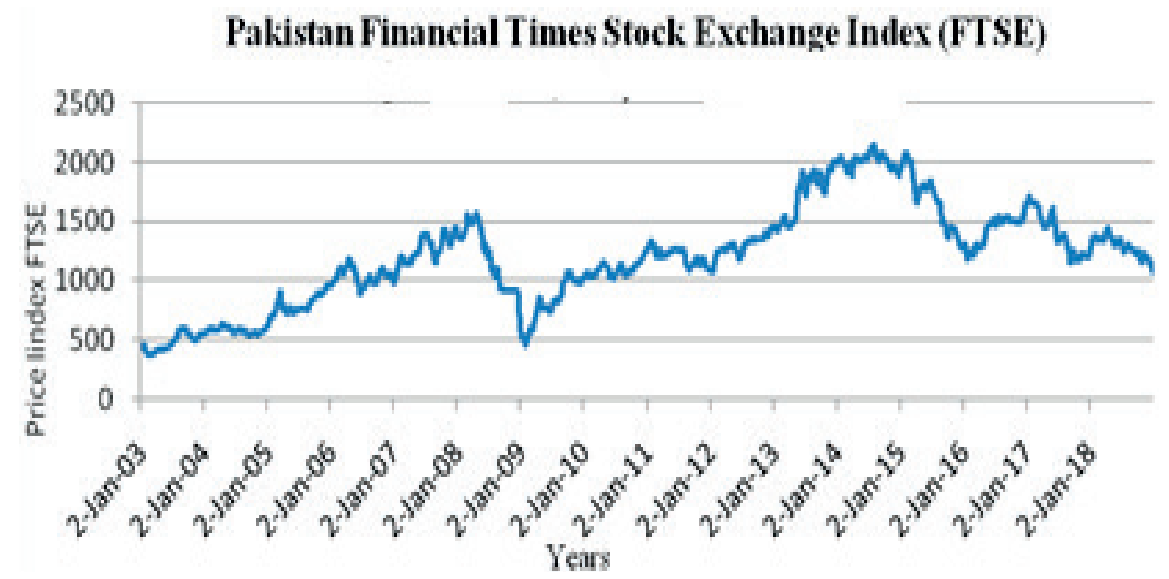

Figure 7. Trend of Pakistan FTSE

Source: Yahoo Finance.

\section{Socio-economic development reasons and COVID-19 pandemic}

The weak economy of the country resulted in a weak healthcare system, hyperinflation, and unemployment. PIDE's COVID-19 e-book (2020) stated that the COVID-19 affected employment, and about $56 \%$ of the total employment is affected in the worst-case scenario. It is feared that 125 million people will fall into poverty, and it is projected that the poverty rate will increase from $23.4 \%$ (baseline poverty) to $33.7 \%$ (in the case of the low-impact scenario), 44.2\% (a medium-impact scenario), or 58.6\% (a high impact scenario). A more prolonged economic recession would push these people into poverty. Poverty has risen massively, and it increased the venerability of many to illegal acts, such as crime, target killings, and mercenaries. Notably, the economic crises also raised illiteracy levels.

In Pakistan, political instability has been a significant issue in strengthening states' social and economic perspectives. The rifts between the political parties, the leftist/rightist separate ideological narratives, pursuing self-interest based policies, protests, sit-ins, and demonstration distracted the nation from a collective story of ensuring an appropriate emergency response like China, state security, and sovereignty. On the other hand, corruption contributes to havoc in the socio-economic development of the country. It is a curse and the primary obstacle to the progress of Pakistan. Moreover, it has destroyed the merit and transparency in the institutions which are crippled and hijacked by interest groups. Consequently, the lack of transparency and accountability has raised issues, such as illegal acts and crime, which impede the health care system is running, peace, and security. 


\section{Conclusion and policy inferences}

Natural disasters (like the COVID-19 pandemic, earthquakes, and floods), poor governance, currency depreciation, less foreign investment, lower returns, and terrorism influence Pakistan's economy. Overall, data findings and a study of the literature show that after the CPEC Pakistani market emerged internationally. Pakistan's socio-economic development can be achieved by combating the COVID-19 effects through effectively utilizing CPEC and better reforms, policies, and governance control. Furthermore, Pakistan should focus more on self-efficiency, internationalization, regional financial integration, domestic exports, and regional development. China-Pakistan's important initiative of trade in domestic currencies will help both countries' sustainable development. Second, strategic communication can be expanded between China-Pakistan on bilateral relations and regional issues of common concern. Third, they should promote pragmatic cooperation and a friendly exchange approach worldwide. Fourth, it will strengthen coordination and cooperation in foreign and local affairs and shared prosperity in the region and globally. Pakistan's geostrategic environment can play a remarkable role in Asia.

The tremendous impact of CPEC and China and Pakistan's mutual assistance is an excellent example for CEECs. There are lessons CEECs can learn from the successful mutual assistance and cooperation. The ongoing COVID-19 pandemic has severe, direct and indirect, long-term socio-economic impacts on developed and developing countries. Pakistan is trying its best to cope with the COVID-19 pandemic. The Government announced the closure of all schools, colleges, and universities with a smart lockdown across the country, preeminent cities. Simultaneously, the Prime minister of Pakistan launched the Ehsas cash emergency program on April $1^{\text {st }}, 2020$, to ease the poor's economic hardships due to the lockdown and provide assistance not to go hungry. This program covers 12 million families, giving them 12,000 PKR each. Therefore, the total budget is PKR 144 billion.

China fought against this virus with proper planning and efficient risk management strategies that mitigated the COVID-19 pandemic. However, other countries allied with China did not learn and failed to make a profound epidemic preparedness plan by considering the Chinese situation. Pakistan did better in controlling COVID-19. Regional integration, reforms, and control through good governance discourage and alleviate money laundering because such acts discourage FDI. Tax-free economic zones should be established rapidly near highways and railway networks under CPEC to attract more foreign investors. Policies should be made to motivate the private and small-medium sectors to increase exports.

For transparency and effective utilization of regional connectivity through CPEC benefits, it is beneficial to disclose the terms and conditions of the project, which both countries have set through China and Pakistan's agreement. This will boost investors' confidence. A cost-benefit analysis is essential in the continuing period and after completing comprehensive regional connectivity through the CPEC project. In this way, policy-makers and researchers will be able to suggest the best policy options for central governments, 
and it is also necessary for China and Pakistan to form a secured institutional mechanism to monitor the smooth transactions regarding investment and the pace of work in the long-term. The CPEC project is helping more, and its influence has started to reduce corruption and the lack of accountability by bringing together transparency in the merit system. However, these projects and the relationship between both countries are not limited to the above.

Pakistan is an agricultural country, so because of COVID-19, it is the right time to focus more on agriculture productivity and get support, learning, and knowledge sharing from the Chinese Government to boost Pakistan's agricultural sector. Future research should focus on the regional connectivity model of using economic zones to transform agricultural reforms and adopting an e-government system to combat the COVID-19 effects and promote socio-economic development.

CEECs are badly affected by COVID-19, and mutual assistance and cooperation like CPEC between China and Pakistan can help them respond to this pandemic appropriately. This kind of cooperation may better help them to cope with unforeseen pandemics with a joint effort and a closely monitored strategy. These initiatives also improved social development in the region and the equal distribution of resources and shared achievements. If any country is under-developed, it also affects other developed countries due to destabilization and the connectedness of issues. The present study has useful policy implications for CEECs to learn lessons from CPEC.

\section{References}

Abid, M., Ashfaq, A. (2015), CPEC: Challenges and opportunities for Pakistan, "Journal of Pakistan Vision”, 16 (2), pp. 142-169, http://pu.edu.pk/images/journal/studi es/PDF-FILES/Artical-7_v16_2_2015.pdf (accessed: 15.12.2019).

Acemoglu, D., Robinson, J. (2013), Why nations fail: the origins of power, prosperity and poverty, Profile Books, London. https://doi.org/10.1111/dpr.12048

Aftab, M.A. (2018), China Pakistan Economic Corridor; Prospects and Challenges for Baluchistan, Pakistan, IOP Conference Series: Materials Science and Engineering, 414, IOP Publishing, https://www.researchgate.net/publication/327638000_China -Pakistan_Economic_Corridor_Prospects_and_Challenges_for_Balochistan_Pa kistan (accessed: 15.12.2019).

Ahmad, Z., Abdullah, N.M.H., Roslan, S. (2012), Capital structure effect on firms performance: Focusing on consumers and industrials sectors on Malaysian firms, "International Review of Business Research Papers", 8 (5), pp. 137-155, https://citese erx.ist.psu.edu/viewdoc/download?doi=10.1.1.458.8815\&rep=rep1\&type $=$ pdf (accessed: 15.12.2019).

Ali, R., Afzal, M. (2012), Impact of the global financial crisis on stock markets: Evidence from Pakistan and India, "E3 Journal of Business Management and Economics", 3 (7), pp. 275-282, https://www.e3journals.org/cms/articles/1342846725_Afzal.pdf (accessed: 15.12.2019). 
Ashraf, B.N., Arshad, S., Yuancheng, H. (2016), Capital regulation and bank risk-taking behavior: Evidence from Pakistan, "International Journal of Financial Studies", 4 (3), pp. 1-20, https://doi.org/10.3390/ijfs4030016

Butt, K.M., Butt, A.A. (2015), Impact of CPEC on Regional and Extra-Regional Actors, "Journal of Political Science", XXXIII, pp. 23-44, http://ps.gcu.edu.pk/wp-content /uploads/2015/02/Butt-Butt.pdf (accessed: 15.12.2019).

Dasgupta, S. (2016), First financing by China-backed AIIB goes to the Silk Road plan in Pakistan, "Times of India”, May 2, http://timesofindia.indiatimes.com/world/ch ina/First-financing-byChina-backed-AIIB-goes-to-Silk-Road-plan-inPakistan/ar ticleshow/52082622.cms (accessed: 2.05.2015).

Fouzia, H.A., Aban, A.Q. (2018), Exploring the Awareness of China Pakistan Economic Corridor: A Stakeholders Perspective, "A Research Journal of South Asian Studies", 33 (1), pp. 97-116, https://www.researchgate.net/publication/325846861_Exploring _the_Awareness_of_China_Pakistan_Economic_Corridor_A_Stakeholder's_Pers pective (accessed: 15.12.2019).

Hussain, M., Mehmood, S., Saeed N. (2017), SWOT analysis of the China - Pakistan economic corridor (CPEC), "Quarterly Journal of Chinese Studies", 5 (2), pp. $42-$ 64, https://www.researchgate.net/profile/Sumara-Mehmood/publication/3217138 63_SWOT_Analysis_of_the_China-_Pakistan_Economic_Corridor_CPEC/links 15a321932458515afb613d60f/SWOT-Analysis-of-the-China-Pakistan-Economic-C orridor-CPEC.pdf (accessed: 15.12.2019).

Law, S., Tan, H.B., Azman-Saini, W.N.W. (2015), Globalization, Institutional Reforms, and Financial Development in East Asian Economies, "The World Economy”, 38 (2), pp. 379-398, https://doi.org/10.1111/twec.12168

Lee, P.T.W., Hu, Z.H., Lee, S.J., Choi, K.S., Shin, S.H. (2017), Research trends and agenda on the Belt and Road (B\&R) initiative with a focus on maritime transport, "Maritime Policy \& Management”, 45 (3), pp. 282-300, https://doi.org/10.1080/030888 39.2017.1400189

Liu, X., An, H., Wang, L., Jia, X., (2017), An integrated approach to optimizing moving average rules in the EUA futures market based on particle swarm optimization and genetic algorithms, “Applied Energy", 185 (2), pp. 1778-1787, https://doi.org/10.10 16/j.apenergy.2016.01.045

Merton, R.C., Bodie, Z. (1995), A Conceptual Framework for Analyzing the Financial System, Harvard Business School Press, Boston.

Pakistan Economic Survey (2017-2018), http://www.finance.gov.pk/survey_1718.html (accessed: 26.04.2018).

Patro, D.K., Wald, J.K., Wu, Y. (2014), Currency devaluation and stock market response: An empirical analysis, "Journal of International Money and Finance", 40, pp. 7994, https://www.researchgate.net/publication/256002940_Currency_Devaluation _and_Stock_Market_Response_An_Empirical_Analysis (accessed: 15.12.2019).

Piazza, J.A. (2006), Rooted in poverty? Terrorism, poor economic development, and social cleavages, "Terrorism and Political Violence”, 18 (1), pp. 159-177, https://doi.org /10.1080/095465590944578

PIDE COVID-19 E-book (2020), https://www.pide.org.pk/pdf/PIDE-COVID19-EBo ok.pdf (accessed: 21.03.2021). 
Rahman, S., Rahman, M., Gilmour, S., Swe, K.T., Abe, S.K., Shibuya, K. (2018), Articles Trends in, and projections of, indicators of universal health coverage in Bangladesh, 1995-2030: a Bayesian analysis of population-based household data, "The Lancet Global Health", 6 (1), e84-e94, https://doi.org/10.1016/S2214-109X(17)30413-8

Rehman, R.U., Zhang, J., Ali, R. (2014), Firm Performance, and Emerging Economies, "Journal of Applied Business Researc", 30 (3), pp. 701-714, https://doi.org/10.19030 /jabr.v30i3.8554

South Asia Portal (Dezember 2019), https://www.satp.org/datasheet-terrorist-attack /official-data/pakistan (accessed: 29.01.2020).

South Asia Terrorism Portal, http://www.satp.org (accessed: 15.12.2019).

State Bank of Pakistan (2017), https://www.sbp.org.pk/reports/annual/arFY17/Anul-in dex-eng-17.htm (accessed: 31.10.2017).

State Bank of Pakistan (2019), https://www.sbp.org.pk/Ecodata/Foreign_Dir.pdf (accessed: 2.12.2019).

Tambo, E., Khayeka-Wandabwa, C., Wagithi, G., Liu, Y., Tang, S., Zhou, X. (2019), China's Belt and Road Initiative: Incorporating public health measures toward global economic growth and shared prosperity, "Global Health Journal”, 3 (2), pp. 46-49, https://doi.org/10.1016/j.glohj.2019.06.003

Yahoo Finance (2019), https://finance.yahoo.com/quote/WIPAK.FGI/ (accessed: 28.02.2019).

\section{Przegląd powiązań regionalnych i reform rozwoju społeczno-gospodarczego przed i po wystąpieniu pandemii COVID-19: czego mogą się nauczyć państwa Europy Środkowej i Wschodniej na przykładzie Korytarza Gospodarczego Chiny-Pakistan?}

Niniejszy artykuł ma na celu podkreślenie roli wzajemnej pomocy w ramach powiązań regionalnych Chin i Pakistanu realizowanych za pośrednictwem Korytarza Gospodarczego Chiny-Pakistan (CPEC) oraz wskazanie wniosków dla państw Europy Środkowej i Wschodniej. CPEC promuje handel, bezpośrednie inwestycje zagraniczne (BIZ), pokój i zrównoważony rozwój społeczno-gospodarczy, a także może pomóc w łagodzeniu skutków COVID-19 w regionie w celu promowania rozwoju społeczno-gospodarczego. W badaniu tym zastosowano metodę „Rolling Window” do analizy danych sprzed i po pojawieniu się pandemii COVID-19. Artykuł prezentuje również wpływ sytuacji przed i po wprowadzeniu inicjatywy CPEC na gospodarkę Pakistanu za pomocą podejścia "Rolling Window” i graficznej prezentacji trendów. Dzięki CPEC, handel, BIZ, wielkość przekazów pieniężnych i indeks giełdy papierów wartościowych (PSX) w Pakistanie wykazały wzrosty. Zmniejszył się terroryzm, co jest pozytywnym sygnałem dla pokoju i rozwoju społeczno-gospodarczego. Nastąpiła jednak zwiększona deprecjacja waluty a kurs walutowy rośnie w stosunku do dolara, szkodząc gospodarce w kilku aspektach, takich jak bilans płatniczy, deficyt na rachunku obrotów bieżących 
i spadek części eksportu. Aby złagodzić te problemy, Pakistan i Chiny podjęły kroki zgodnie z formułą handlu w walucie krajowej między Chinami a Pakistanem. Podczas pandemii COVID-19 zapewnienie na zasadzie pierwszeństwa dostaw sprzętu dla opieki zdrowotnej z Chin pomogło w zwalczaniu skutków COVID-19 i ustabilizowaniu gospodarki Pakistanu. CPEC został skonstruowany z zamiarem połączenia regionalnych stref ekonomicznych poprzez tworzenie lokalnych, regionalnych i globalnych łańcuchów wartości. Aby poradzić sobie ze skutkami COVID-19, państwom Europy Środkowej i Wschodniej zaleca się reformy społeczno-gospodarcze i współpracę regionalną, po uprzednim przeanalizowaniu ich specyficznej sytuacji. Integracja i współpraca regionalna mają kluczowe znaczenie dla radzenia sobie z tą pandemią. Kraje Europy Środkowej i Wschodniej mogą wyciągnąć wnioski z przykładu CPEC w zakresie rozwoju społeczno-gospodarczego, ograniczenia przemocy i poprawy sytuacji gospodarki.

Słowa kluczowe: Korytarz Gospodarczy Chiny-Pakistan (CPEC), kurs wymiany, BIZ, przemoc, technologia, rozwój społeczno-gospodarczy, pandemia COVID-19 